\title{
THE QUALITY OF THE DEPARTMENT OF LIBRARY SCIENCE'S WEBSITE BY WEBQUAL 4.0
}

\author{
Andi Ibrahim*, Touku Umar*, \& Feri Ardinata*
}

*Program Studi Ilmu Perpustakaan, Universitas Islam Negeri Alauddin Makassar
Email: andiibrahim232@gmail.com

(Submitted: 03-11-2020, Revised: 30-12-2020, Accepted: 30-12-2020)

DOI: $10.2425 /$ kah.v8i2a11

\begin{abstract}
ABSTRAK: Penelitian ini membahas tentang kualitas website Program Studi Ilmu Perpustakaan Universitas Islam Negeri Alauddin Makassar sebagai media informasi menggunakan metode WebQual 4.0. Tiga variabel pengukuran yang digunakan yakni: kualitas penggunaan (Usability Quality), kualitas informasi (Information Quality), dan kualitas interaksi (Interaction Quality). Penelitian deskriptif ini menggunakan pendekatan kuantitatif dalam menyajikan data. Data penelitian diperoleh melalui kuesioner online dan juga observasi website. Populasi dalam penelitian ini adalah 448.440 jumlah pengunjung website dan sampel sebanyak 100 orang mahasiswa responden yang ditentukan dengan teknik sampling insidental. Uji validitas dan reliabilitas menggunakan bantuan Software SPSS 23. Hasil penelitian menunjukkan bahwa kualitas penggunaan (usability) dan kualitas informasi (information quality) website Jurusan Ilmu Perpustakaan UIN Alauddin Makassar adalah berada pada ketegori baik dengan persentase $75,1 \%$ dan $73,7 \%$. Sedangkan, kualitas interaksi (interaction quality) ada pada kategori sangat baik dengan persentase $81,5 \%$. Sehingga dapat dikatakan kualitas website ini berada dalam kategori baik.
\end{abstract}

Kata kunci: WebQual 4.0; Website

ABSTRACT: This research discusses the quality of the website of the Library Science Study Program Universitas Islam Negeri Alauddin Makassar as a medium of information using the WebQual 4.0 method. Three measurement variables are used, namely: Usability Quality, Information Quality, and Interaction Quality. This descriptive study uses a quantitative approach in presenting data. The data were obtained through online questionnaires and website observations. The population in this study was 448,440 the number of website visitors and a sample of 100 student respondents who were determined by incidental sampling technique. The validity and reliability tests used SPSS 23 software. The results showed that the quality of usability and information quality of the website of the Department of Library Science UIN Alauddin Makassar were in the good category with a percentage of $75.1 \%$ and $73.7 \%$. Meanwhile, the interaction quality is in the very good category with a percentage of $81.5 \%$. So it can be said that the quality of this website is in a good category.

Keywords: WebQual 4.0; Website

\section{PENDAHULUAN}

Perkembangan teknologi informasi khususnya di instansi pendidikan universitas yang semakin pesat sehingga membawa dampak kepada mahasiswa dapat dengan mudah mendapatkan informasi yang cepat, tepat serta dapat diakses dengan mudah dimanapun mereka berada. Salah satu pemanfaatan teknologi informasi yang digunakan mahasiswa adalah website. Website informasi sebagai bentuk yang mendekatkan sebuah instansi kepada pengguna mahasiswa tanpa dihalangi jarak dan waktu. Mahasiswa dapat memperoleh informasi secara online tanpa harus ke datang secara langsung ke tempat. Oleh karena itu, sebuah instansi harus 
Andi Ibrahim, Touku Umar, \& Feri Ardinata: The Quality of the Department of Library Science's website by WebQual 4.0

membangun website dan mengembangkan website yang dimiliki oleh untuk memberikan informasi tersebut.

Website adalah salah satu media penting dimana pengguna dapat menemukan semua jenis informasi yang berkaitan dengan bidang mereka. Salah satu domain dimana yang paling banyak digunakan saat ini adalah domain akademik (Perguruan Tinggi/Universitas) (Kothainayaki, dkk., 2012). Jurusan Ilmu Perpustakaan UIN Alauddin Makassar memiliki website informasi yaitu http://ipi.fah.uin-alauddin.ac.id. Website informasi tersebut merupakan salah satu media online yang digunakan untuk memberikan informasi untuk mahasiswa jurusan ilmu perpustakaan. Website tersebut memberikan pelayanan informasi berita seputar jurusan ilmu perpustakaan. Informasi yang diunggah adalah informasi penting tentang jurusan ilmu perpustakaan dan informasi jurusan seperti visi \& misi, pimpinan, dosen dan staf, informasi kemahasiswaan, kerjasama, pengabdian masyarakat, kontak, e-learning dan document yang dapat didownload serta berita kegiatan lainnya di jurusan ilmu perpustakaan. Berdasarkan situs statshow.com mencatat ipi.fah.uin-alauddin.ac.id telah meningkat $54 \%$ selama 3 bulan terakhir di mana saat in telah mencapai 448.440 pengunjung.

Penelitian ini bertujuan untuk menganalisis kualitas dari website Jurusan Ilmu perpustakaan yang beralamatkan pada http://ipi.fah.uin-alauddin.ac.id dengan menggunakan metode WebQual 4.0 menurut persepsi dari pada pengguna situs tersebut. Penilaian yang dilakukan oleh responden berdasarkan metode WebQual 4.0 yaitu Usability Quality, Information Quality dan Service Interaction quality. Selain itu, hasil dari analisis yang dilakukan terhadap penilaian asribut kualitas website jurusan Ilmu Perpustakaan UIN Alauddin Makassar yang kemudian dapat menjadi feedback atau umpan balik bagi jurusan sebagai indikator dalam menentukan kualitas mana saja yang telah sesuai dengan keinginan pengguna dan mana saja yang membutuhkan perbaikan bagi kemajuan website jurusan di masa yang akan datang.

\section{KAJIAN TERDAHULU}

Kepuasan masyarakat merupakan salah satu faktor atau ukuran keberhasilan bagi setiap pengembangan sistem informasi suatu pemerintahan. Kualitas layanan yang baik tidak hanya berdasarkan pada sudut pandang atau persepsi pihak penyedia layanan, tetapi juga berdasarkan pada sudut pandang atau persepsi masyarakat. Masyarakat yang menikmati layanan adalah masyarakat yang dapat menentukan kualitas layanan. Persepsi masyarakat terhadap kualitas layanan merupakan penilaian menyeluruh atas keunggulan suatu layanan. Webqual 4.0 merupakan metode untuk mengetahui kualitas website berdasarkan persepsi masyarakat atau pengguna. Metode webqual 4.0 terdiri atas tiga kategori yaitu usability, information quality, dan interaction quality. Ketiga kategori tersebut dijadikan acuan dalam pembuatan kuesioner untuk menganalisis kualitas website.

Beberapa kajian terkait kualitas website di beberapa lembaga telah sering dilakukan. Barnes \& Vidgen (2003) membahas tentang penggunaan metode WebQual dalam mengukur peningkatan kualitas website. Abbas (2013) dalam prosidingnya menunjukkan kepuasan mahasiswa terhadap website Universitas Negeri Yogyakarta dengan menggunakan tiga variabel pengukuran yakni usability, information quality, dan services interaction. Ketiga variabel tersebut punya pengaruh signifikan terhadap kepuasan penggunanya (Pratama \& Kusomo, 2015), (Rerung, Fauzan, \& Hermawan, 2020). Penelitian lainnya menyatakan bahwa kualitas layanan website dipengaruhi oleh konten website itu sendiri (Tristiyanto, Saputri, \& Iqbal, 2020). Sementara itu, dari hasil penelitian yang dilakukan oleh Nada \& Wibowo (2015) bahwa hanya satu variabel WebQual 4.0, yaitu Service Interaction Quality yang berpengaruh signifikan terhadap kepuasan pengguna website sistem akademik universitas. Berbeda dengan kedua kajian terakhir yang disebutkan, Nugroho dan Sari (2016) menemukan hasil yang berbeda yang mengatakan bahwa berdasarkan pengaruh ketiga variabel WebQual, terdapat dua variabel yang berpengaruh secara positif dan signifikan terhadap kepuasan pengguna yaitu usability dan service interaction. Sedangkan variabel information quality tidak berpengaruh positif dan signifikan terhadap kepuasan pengguna. Sebaliknya, temuan Winarti \& Munggaran (2014) 
bahwa ada gap atau kesenjangan antara persepsi dan harapan pengguna pada dimensi information quality.

Dari kajian-kajian yang disebutkan di atas menunjukkan bahwa website yang menjadi objek penelitian pada masing-masing kajian tersebut memiliki perbedaan antar satu sama lain. Oleh karena itu pentingnya ketiga variabel tersebut terpenuhi dengan baik, agar pengguna website dapat merasa puas. Bahkan sebuah website, yang dalam konteks ini ialah perguruan tinggi, dapat mempengaruhi pengambilan keputusan bagi siapa saja untuk memilih sebuah universitas sebagai tujuannya menimba ilmu (Frisdiantara, Qamar, Ardian, \& Rahman, 2020).

\section{METODOLOGI PENELITIAN}

Penelitian ini menggunakan deskriptif kuantitatif. Metode yang digunakan yaitu metode survey, dimana untuk mendapatkan data mengenai fenomena atau gejala suatu kelompok atau individu dilakukan dengan memberikan daftar pertanyaan atau pernyataan kepada responden. Populasi yang digunakan untuk penelitian ini yaitu peneliti mengambil populasi dari dari jumlah pengunjung website jurusan ilmu perpustakaan menggunakan tools untuk mengetahui jumlah pengunjung website. Adapun jumlah pengunjung website adalah sebanyak 448.440. Metode pengambilan sampel yang digunakan dalam penelitian ini adalah Nonprobability Sampling, yaitu teknik sampling insidental.

Berdasarkan populasi yang ditemukan peneliti sebanyak 448.440 pengguna, maka peneliti menggunakan Rumus Slovin dalam menentukan sampel untuk mewakili jumlah populasi yang sudah mengunjungi website Jurusan Ilmu Perpustakaan UIN Alauddin sehingga dapat mewakili dalam memberikan penilaian kualitas website berdasarkan metode WebQual 4.0.

Rumus Slovin:

$$
n=\frac{N}{1+\left(N x e^{2}\right)}
$$

Keterangan :

$$
\begin{aligned}
& n=\text { Ukuran Sampel } \\
& \mathrm{N}=\text { Ukuran Populasi } \\
& e=\text { Error level (tingkat kesalahan) }
\end{aligned}
$$

catatan: umumnya digunakan $1 \%$ atau 0,01 , atau $5 \%$ atau 0,05 , dan $10 \%$, atau 0,1 (dapat dipilih oleh peneliti) (Noor,2011:158).

Berdasarkan rumus di atas, maka jumlah sampel pada penelitian ini adalah:

$$
\begin{gathered}
n=\frac{N}{1+\left(N x e^{2}\right)} \\
n=\frac{448.440}{1+\left(448.440 \times 0.1^{2}\right)} \\
n=\frac{448.440}{1+(448.440 \times 0.01)} \\
n=\frac{448.440}{1+4484.4} \\
n=\frac{448.440}{4485.4} \\
n=99,97 \sim 100 \text { responden }
\end{gathered}
$$

Teknik yang digunakan untuk mengumpulkan data yaitu Observasi dan Kuesioner. Penelitian ini menggunakan kuesioner elektronik secara online (melalui Google Docs). Kuesioner ini dibagikan melalui media sosial seperti facebook, whatsapp serta media sosial lainnya untuk memudahkan peneliti dalam mengumpulkan data penelitian dengan memberikan responden kuesioner yang berupa pernyataan yang berkaitan dengan kualitas website Jurusan Ilmu Perpustakaan UIN Alauddin Makassar berdasarkan metode WebQual 4.0. Teknik pengolahan dan 
analisis data yang digunakan adalah analisis dan statistik deskriptif. Data yang diperoleh ditabulasikan dengan menyusun data kedalam tabel kemudian dihitung persentasenya, berdasarkan bobotnya. Adapun untuk memperoleh data angket yang telah di tabulasikan dan persentase digunakan rumus:

Keterangan:

$$
\mathrm{P}=\frac{F}{N} \mathrm{X} 100
$$

$\mathrm{P}=$ Angka Persentase

$\mathrm{F}=$ Frekuensi yang sedang di cari persentase

$\mathrm{N}=$ Jumlah Frekuensi atau jumlah responden

$100 \%=$ Angka pembulat (Sugiyono, 2005:43)

Dalam penelitian ini penulis akan membagi kategori kualitas website Jurusan Ilmu Perpustakaan UIN Alauddin Makassar ke dalam 5 bagian, yaitu kategori sangat tidak baik, tidak baik, cukup baik, baik dan sangat baik.

Tabel 1. Kategori jawaban

\begin{tabular}{cccccc}
\hline \multirow{2}{*}{ No. Kuesioner } & SS & S & RR & TS & STS \\
& $\mathbf{5}$ & $\mathbf{4}$ & $\mathbf{3}$ & $\mathbf{2}$ & $\mathbf{1}$ \\
\hline 1 & 22 & 52 & 16 & 8 & 2 \\
2 & 21 & 38 & 32 & 8 & 1 \\
3 & 12 & 42 & 31 & 13 & 2 \\
4 & 15 & 57 & 18 & 8 & 2 \\
5 & 28 & 30 & 28 & 7 & 7 \\
6 & 28 & 43 & 21 & 8 & 0 \\
7 & 25 & 40 & 26 & 6 & 3 \\
8 & 33 & 39 & 19 & 5 & 4 \\
Jumlah & $\mathbf{1 8 4}$ & $\mathbf{3 4 1}$ & $\mathbf{1 9 1}$ & $\mathbf{6 3}$ & $\mathbf{2 1}$ \\
\hline
\end{tabular}

Adapun skala pengukuran dalam penelitian ini penulis menggunakan Skala Likert. Jadi, gradasi yang penulis gunakan adalah sebagai berikut:

Tabel 2. Skala Likert

\begin{tabular}{lc}
\hline Jawaban & Skor \\
\hline Sangat Tidak Setuju & 1 \\
Tidak Setuju & 2 \\
Ragu-Ragu & 3 \\
Setuju & 4 \\
Sangat Setuju & 5 \\
\hline
\end{tabular}

\section{HASIL DAN PEMBAHASAN}

\section{Karakteristik Responden}

Tabel 3 Karakteristik responden berdasarkan jenis kelamin

\begin{tabular}{clcc}
\hline No. & Jenis Kelamin & Frekuensi & Persentase (\%) \\
\hline 1. & Pria & 31 & $31 \%$ \\
2. & Wanita & 69 & $69 \%$ \\
& Jumlah & $\mathbf{1 0 0}$ & $\mathbf{1 0 0 \%}$ \\
\hline
\end{tabular}


Tabel 4. Karakteristik responden berdasarkan usia

\begin{tabular}{cccc}
\hline No. & Usia & Frekuensi & Persentase (\%) \\
\hline 1. & $\leq 19$ Tahun & 23 & $23 \%$ \\
2. & 20-22 Tahun & 50 & $50 \%$ \\
3. & $\geq 23$ Tahun & 27 & $27 \%$ \\
& Jumlah & $\mathbf{1 0 0}$ & $\mathbf{1 0 0 \%}$ \\
\hline
\end{tabular}

\section{Kualitas Penggunaaan (Usability Quality)}

Adapun kriteria yang diambil adalah responden yang pernah mengujungi website Jurusan Ilmu Perpustakaan UIN Alauddin Makassar dan dapat memberikan penilaian terhadap kualitas website tersebut.

Kualitas Penggunaan (Usability Quality) terhadap website Jurusan Ilmu Perpustakaan UIN Alauddin Makassar menggunakan metode WebQual 4.0. Jumlah item untuk pernyataan variabel Kualitas Penggunaan (Usability Quality) ada 8 item. Dari hasil pengolahan data tentang Kualitas Penggunaan (Usability Quality) maka rekapitulasi jawaban responden dan total skor pernyataan variabel tersebut dapat dilihat pada tabel berikut:

Tabel 5. Total skor jawaban resonden

\begin{tabular}{lccc}
\hline Penilaian & $\begin{array}{c}\text { Skor } \\
\text { (S) }\end{array}$ & $\begin{array}{c}\text { Frekuensi } \\
\text { (F) }\end{array}$ & (S) X (F) \\
\hline Sangat Setuju & 5 & 184 & 920 \\
Setuju & 4 & 341 & 1364 \\
Ragu-Ragu & 3 & 191 & 573 \\
Tidak Setuju & 2 & 63 & 126 \\
Sangat tidak Setuju & 1 & 21 & 21 \\
Jumlah & & $\mathbf{8 0 0}$ & $\mathbf{3 0 0 4}$ \\
\hline
\end{tabular}

(Sumber: diolah 15 Februari 2020)

Dari tabel di atas dapat diketahui total skor variabel Kualitas Penggunaan (Usability Quality) adalah 3004. Pengkategorian didasarkan pada rentang skor di mana:

a) Jumlah skor maksimal diperoleh dari 5 (skor tertinggi) dikali jumlah item pernyataan dikali jumlah responden, yaitu: 5 × 8 × $100=4000$.

b) Jumlah skor minimal diperoleh dari 1 (skor terendah) dikali jumlah item pernyataan dikali jumlah responden, yaitu: 1 × 8 × $100=800$.

Berdasarkan rentang skor tersebut diperoleh tingkatan pengelompokan penilaian responden terhadap Kualitas Penggunaan (Usability Quality) terhadap website Jurusan Ilmu Perpustakaan UIN Alauddin Makassar seperti yang digambarkan pada garis kontinum sebagai berikut: 
Rentang Skor Kualitas Penggunaan (Usability Quality)

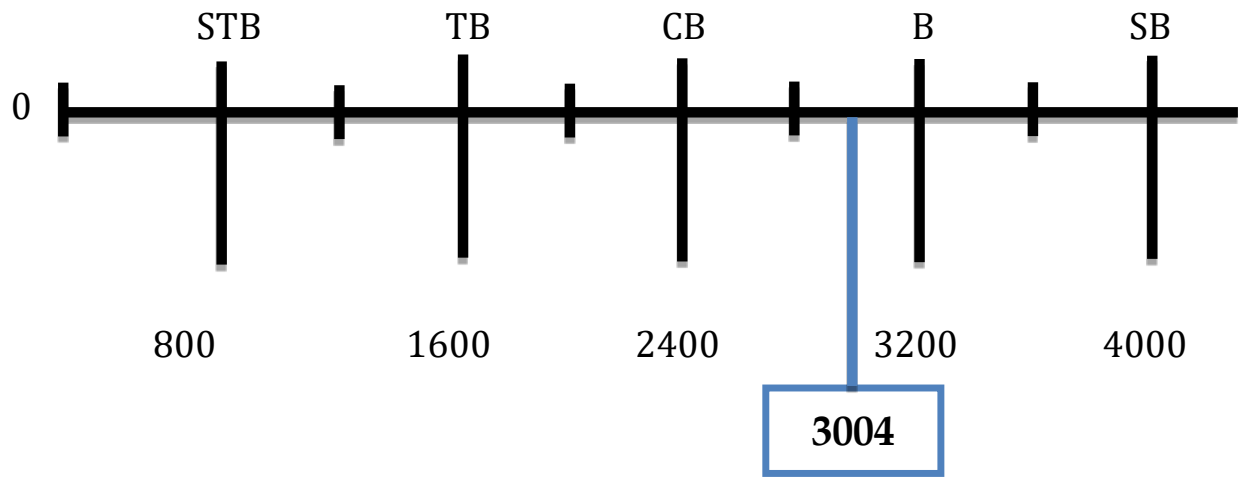

Keterangan:

$\begin{array}{ll}\text { STB } & \text { : Sangat tidak Baik } \\ \text { TB } & \text { : Tidak Baik } \\ \text { CB } & \text { : Cukup Baik } \\ \text { B } & \text { : Baik } \\ \text { SB } & \text { : Sangat Baik }\end{array}$

Untuk mengetahui nilai persentase digunakan rumus:

$$
\begin{aligned}
& \mathrm{P}=\frac{\text { Skor Total }}{\text { Skor Maksimal }} \times 100 \% \\
& \mathrm{P}=\frac{3004}{4000} \times 100 \% \\
& \mathrm{P}=75,1 \%
\end{aligned}
$$

Dengan demikian berdasarkan penilaian 100 responden, skor variable kualitas penggunaan (Usability Quality) sebesar 3004 termasuk kategori interval "cukup baik dan baik" (2400-3200). Kemudian nilai persentasenya 75,1\% masuk kategori baik. Hal ini menunjukkan bahwa kualitas penggunaan (Usability Quality) pada website Jurusan Ilmu Perpustakaan UIN Alauddin Makassar adalah "Baik" karena berada pada rentang skor kualitas 2400-3200 atau $75,1 \%$.

\section{Kualitas Informasi (Information Quality)}

Kualitas informasi (Information Quality) terhadap website Jurusan Ilmu Perpustakaan UIN Alauddin Makassar menggunakan metode WebQual 4.0. Jumlah item untuk pernyataan variabel kualitas informasi (Information Quality) ada 7 item. Dari hasil pengolah data tentang kualitas informasi (Information Quality) maka rekapitulasi jawaban responden dan total skor pernyataan variabel tersebut dapat dilihat pada tabel berikut:

Tabel 6. Total skor pernyataan responden

\begin{tabular}{lccc}
\hline Penilaian & $\begin{array}{c}\text { Skor } \\
\text { (S) }\end{array}$ & $\begin{array}{c}\text { Frekuensi } \\
\text { (F) }\end{array}$ & (S) X (F) \\
\hline Sangat Setuju & 5 & 132 & 660 \\
Setuju & 4 & 313 & 1252 \\
Ragu-Ragu & 3 & 176 & 528 \\
Tidak Setuju & 2 & 70 & 140 \\
Sangat tidak Setuju & 1 & 0 & 0 \\
Jumlah & & $\mathbf{6 9 1}$ & $\mathbf{2 5 8 0}$ \\
\hline
\end{tabular}

(Sumber: diolah pada tanggal 16 Februari 2020) 
Dari tabel dapat diketahui total skor variabel Kualitas Informasi (Information Quality) adalah 2580. Pengkategorian didasarkan pada rentang skor dimana:

a) Jumlah skor maksimal diperoleh dari 5 (skor tertinggi) dikali jumlah item pernyataan dikali jumlah responden, yaitu: 5 × 7 × $100=3500$

b) Jumlah skor minimal diperoleh dari 1 (skor terendah) dikali jumlah item pernyataan dikali jumlah responden, yaitu: 1 × 7 x $100=700$.

Berdasarkan rentang skor tersebut diperoleh tingkatan pengelompokan penilaian responden Jurusan Ilmu Perpustakaan UIN Alauddin Makassar seperti yang digambarkan pada garis kontinum sebagai berikut:

\section{Rentang Skor kualitas informasi (Information Quality)}

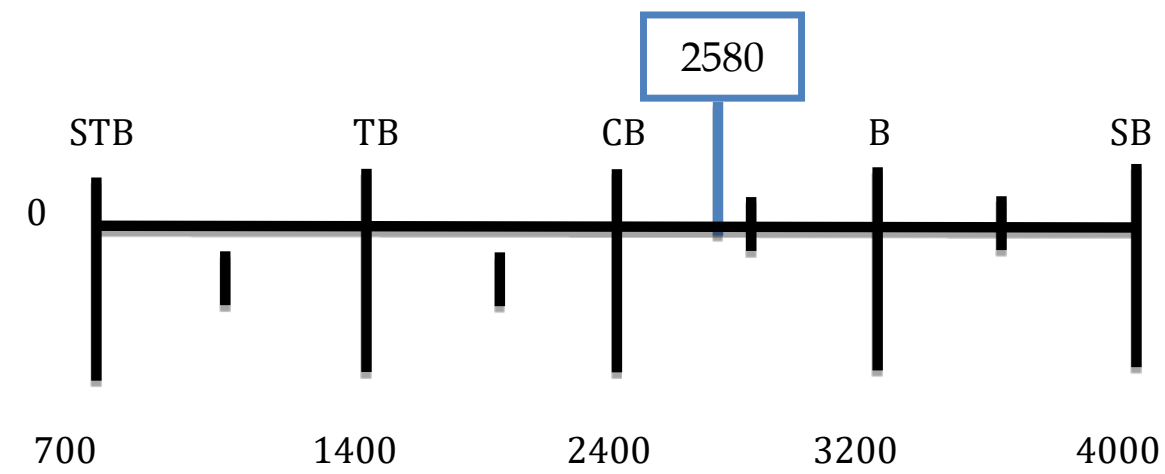

Keterangan:

STB : Sangat tidak Baik

TB : Tidak Baik

CB : Cukup Baik

B : Baik

SB : Sangat Baik

Untuk mengetahui nilai persentase digunakan rumus:

$$
\begin{aligned}
& \mathrm{P}=\frac{\text { Skor Total }}{\text { Skor Maksimal }} \times 100 \% \\
& \mathrm{P}=\frac{2580}{3500} \times 100 \% \\
& \mathrm{P}=73,7 \%
\end{aligned}
$$

Dengan demikian berdasarkan penilaian 100 responden, skor variabel kualitas informasi (Information Quality) sebesar 2580 termasuk kategori interval "cukup baik dan baik" (21003800 ) kemudian nilai persentasenya $73,7 \%$ masuk kategori baik. Hal ini menunjukkan bahwa kualitas informasi (Information Quality) pada website Jurusan Ilmu Perpustakaan UIN Alauddin Makassar adalah "Baik" karena berada pada rentang skor kualitas 2100-3800 atau 73,7\%.

\section{Kualitas Interaksi (Interaction Quality)}

Kualitas interaksi (Interaction quality) terhadap website Jurusan Ilmu Perpustakaan UIN Alauddin Makassar menggunakan metode WebQual 4.0. Jumlah item untuk pernyataan variabel kualitas interaksi (Interaction Quality) adalah 7 item. Dari hasil pengolah data tentang Kualitas interaksi (Interaction Quality) terhadap website Jurusan Ilmu Perpustakaan UIN Alauddin Makassar, maka rekapitulasi jawaban responden dan total skor pernyataan variabel tersebut dapat dilihat pada tabel berikut: 
Tabel 7. Total skor pernyataan responden

\begin{tabular}{lccc}
\hline Penilaian & $\begin{array}{c}\text { Skor } \\
\text { (S) }\end{array}$ & $\begin{array}{c}\text { Frekuensi } \\
\text { (F) }\end{array}$ & (S) X (F) \\
\hline Sangat Setuju & 5 & 230 & 1150 \\
Setuju & 4 & 282 & 1128 \\
Ragu-Ragu & 3 & 124 & 372 \\
Tidak Setuju & 2 & 52 & 104 \\
Sangat tidak Setuju & 1 & 12 & 12 \\
Jumlah & & $\mathbf{7 0 0}$ & $\mathbf{2 7 6 6}$ \\
\hline
\end{tabular}

(Sumber: diolah pada tanggal 16 Februari 2020)

Berdasarkan tabel di atas dapat diketahui total skor variabel kualitas interaksi (Interaction quality) adalah 2766. Pengkategorian didasarkan pada rentang skor dimana:

a) Jumlah skor maksimal diperoleh dari 5 (skor tertinggi) dikali jumlah item pernyataan dikali jumlah responden, yaitu: 5 × 7 × $100=3500$

b) Jumlah skor minimal diperoleh dari 1 (skor terendah) dikali jumlah item pernyataan dikali jumlah responden, yaitu: 1 x 7 x $97=700$.

Berdasarkan rentang skor tersebut diperoleh tingkatan penilaian kualitas interaksi (Interaction quality) terhadap terhadap website Jurusan Ilmu Perpustakaan UIN Alauddin Makassar. Hal ini dapat dibuat kategori sebagai berikut:

Rentang Skor kualitas interaksi (Interaction quality)

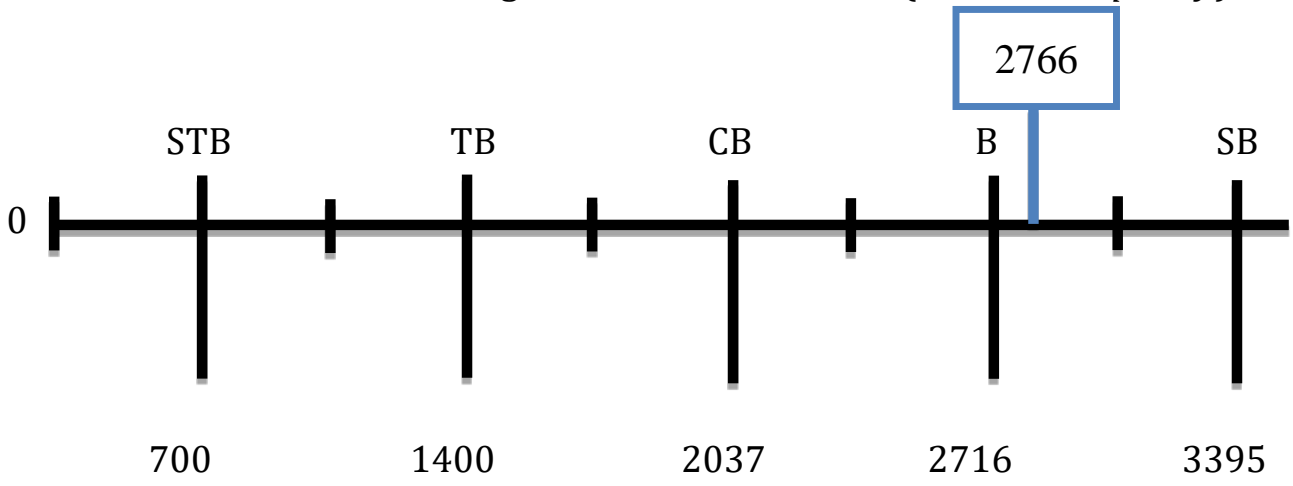

Keterangan:

STB : Sangat tidak Baik

TB : Tidak Baik

CB : Cukup Baik

B : Baik

SB : Sangat Baik

Untuk mengetahui nilai persentase digunakan rumus:

$$
\begin{aligned}
& \mathrm{P}=\frac{\text { Skor } \text { Total }}{\text { Skor } \text { Maksimal }} \times 100 \% \\
& \mathrm{P}=\frac{2766}{3395} \times 100 \% \\
& \mathrm{P}=81,5 \%
\end{aligned}
$$

Dengan demikian berdasarkan penilaian 100 responden, skor variabel kualitas interaksi (Interaction quality) sebesar 2766 termasuk kategori interval "cukup baik dan baik" (27163395) kemudian nilai persentasenya $81,5 \%$ masuk kategori sangat baik. Hal ini menunjukkan bahwa kualitas informasi (Information Quality) pada website Jurusan Ilmu Perpustakaan UIN 
Alauddin Makassar adalah "Sangat Baik" karena berada pada rentang skor kualitas 2716-3395 atau $81,5 \%$.

\section{KESIMPULAN}

Berdasarkan hasil penelitian dan pembahasan yang telah diuraikan mengenai kualitas website jurusan Ilmu Perpustakaan UIN Alauddin menggunakan metode WebQual 4.0 maka dapat ditarik kesimpulan bahwa dalam pengukuran website berdasarkan metode WebQual 4.0 terdapat 3 variabel penilaian di mana Kualitas Penggunaan (Usability Quality) dan Kualitas Informasi (Information Quality) website Jurusan Ilmu Perpustakaan UIN Alauddin Makassar masuk dalam kategori baik yaitu sebesar 75,1\% dan 73,7\%. Sementara untuk Kualitas Interaksi (Interaction Quality) yaitu sebesar 81,5\% masuk dalam kategori sangat baik. Dari apa yang ditemukan pada ketiga varaibel tersebut dapat dikatakan bahwa kualitas website Jurusan Ilmu Perpustakaan UIN Alauddin Makassar dapat dikategorikan baik.

\section{DAFTAR PUSTAKA}

Abbas, W. (2013). Analisa kepuasan mahasiswa terhadap website Universitas Negeri Yogyakarta (UNY). Prosiding SNST Fakultas Teknik, 1(1), 1-6. Retrieved from https://publikasiilmiah.unwahas.ac.id/index.php/Prosi ding_SNST_FT/article/view/759.

Barnes, S. J., \& Vidgen R. T. (2000). An evaluation of cyber- bookshops: the WebQual method. International Journal of Electronic Commerce (6:1), pp 11-30.

Barnes, S. J. and Vidgen R. T. (2003a). An integrative approach to the assessment of e-commerce quality. Journal of Electronic Commerce Research, 3(3), 114-127.

Barnes, S. J. and Vidgen R. T. (2003b). Measuring Web site quality improvements: a case study of the forum on strategic management knowledge exchange. Industrial Management \& Data Systems. 103(5), 297-309.

Frisdiantara, C., Qamar, K., Ardian, Y., \& Rahman, E. F. (2020). The effect of website quality using webqual 4.0 method on student's decision in registering at university of Kanjuruhan malang. Proceedings of the International Conference on Industrial Engineering and Operations Management. Dubai.

Kothainayaki, S., Sivakumaren, K.S. \& Gopalakrishnan, S., (2012). User preferences on university websites: a study. Library Philosophy and Practice. 788.

Nada, N. Q., \& Wibowo, S. (2015). Pengukuran kualitas layanan sistem informasi akademik menggunakan metode webqual 4.0. Jurnal Informatika UPGRIS, 1(2), 112-119. https://doi.org/10.26877/JIU.V1I2 Desember.870.

Nugroho, A. K., \& Sari, P. K. (2016). Analisis pengaruh kualitas website tokopedia terhadap kepuasan pengguna menggunakan metode webqual 4.0. E-Proceeding of Management, 3(3), 2930-2937.

Pratama, Y. (2015). Pengukuran kualitas website cdc universitas telkom menggunakan metode webqual 4.0. E-Proceeding of Engineering, 2(1), 1649-1658.

Rerung, R. R., Fauzan, M., \& Hermawan, H. (2020). Website quality measurement of higher education services institution region iv using webqual 4.0 method. International Journal of Advances in Data and Information Systems. 1(2).

Sugiyono. (2014). Metodologi Penelitian Bisnis. Cetakan 18. Bandung: Alfabeta

Sugiyono. (2016). Metode Penelitian Kuantitatif, Kualitatif dan $R \& D$. Bandung: Alfabeta.

Tristiyanto, Saputri, D., Iqbal, M. (2020) Implementasi metode webqual dan customer satisfaction index untuk mengevaluasi website perguruan tinggi di Bandar Lampung. Kumpulan Jurnal Ilmu Kompter. 7(1).

Winarti \& Munggaran, L. C. (2014). Pengukuran kualitas situs perguruan tinggi dari sudut pandang pemakai dengan menggunakan metode webqual 4.0. Jurnal Ilmiah Informatika Komputer. 19(3). 